DOI: http://doi.org/10.21698/simi.2018.ab05

\title{
EFFECT OF THE SUPPORT ON THE CATALYTIC ACTIVITY OF COPPER OXIDE IN METHANE COMBUSTION
}

\author{
Ionel Popescu ${ }^{1}$, Nathalie Tanchoux ${ }^{2}$, Didier Tichit ${ }^{2}, \underline{\text { Ioan-Cezar Marcu }}^{1,3}$ \\ ${ }^{1}$ Research Center for Catalysts and Catalytic Processes, Faculty of Chemistry, University of \\ Bucharest, 4-12 Regina Elisabeta Blvd., 030018, Bucharest, Romania \\ ${ }^{2}$ Institut Charles Gerhardt, UMR 5253 CNRS/ENSCM/UM2/UM1, Matériaux Avancés pour la \\ Catalyse et la Santé (MACS), Ecole Nationale Supérieure de Chimie, 8, rue de l'Ecole \\ Normale, 34296, Montpellier Cedex 5, France \\ ${ }^{3}$ Laboratory of Chemical Technology and Catalysis, Department of Organic Chemistry, \\ Biochemistry and Catalysis, Faculty of Chemistry, University of Bucharest, 4-12 Regina \\ Elisabeta Blvd., 030018, Bucharest, ioancezar.marcu@,chimie.unibuc.ro, Romania
}

Keywords: air pollution abatement, $\mathrm{CuO}$-based catalyst, methane combustion

\section{Introduction}

Catalytic combustion is an efficient method for the removal of organic pollutants from air streams needing much lower temperatures than the conventional incineration ( $\mathrm{Li}$ et al 2009). The best catalysts used for volatile organic compounds (VOC) abatement are based on noble metals. However, they have some disadvantages like high sintering rates, volatility, poisoning in presence of water or sulfur compounds and high price. Therefore, transition metal oxides, which possess high thermal stability, resistance to poisoning and low costs, appear very promising catalytic materials for VOC combustion (Chen et al 2015). Due to its high stability, $\mathrm{CH}_{4}$ is often used as a test molecule in catalytic combustion processes. $\mathrm{CuO}$ is among the most effective metal oxide-based catalysts for methane combustion (Chen et al 2015). However, further improvements of its catalytic performance are still necessary to consider the replacement of noble metal-based catalysts in this process. This can be achieved by supporting $\mathrm{CuO}$ on support materials of different nature. In the present work the support influence has been examined using $\mathrm{Al}_{2} \mathrm{O}_{3}, \mathrm{MgO}$ and $\mathrm{Mg}(\mathrm{Al}) \mathrm{O}$ mixed oxides obtained from layered double hydroxides (LDH) precursors.

\section{Materials and methods}

$\mathrm{CuO}$ supported on $\mathrm{Al}_{2} \mathrm{O}_{3}, \mathrm{MgO}$ and $\mathrm{Mg}(\mathrm{Al}) \mathrm{O}$ mixed oxides $(\mathrm{Mg} / \mathrm{Al}$ mol ratios of 1,3 and 5) were prepared by coprecipitation of the corresponding metal nitrates with $\mathrm{NaOH}$, followed by washing with deionized water, drying at $80^{\circ} \mathrm{C}$ and calcination in air at $750^{\circ} \mathrm{C}$. The $\mathrm{Cu} /(\mathrm{Cu}+\mathrm{Mg}+\mathrm{Al}) \mathrm{mol}$ ratio was fixed to 0.05 . The catalysts were noted $\mathrm{CuAlO}, \mathrm{CuMgO}$ and $\mathrm{CuMgAl}(\mathrm{x}) \mathrm{O}(x$ for $\mathrm{Mg} / \mathrm{Al}=1,3$ or 5$)$, respectively. They have been characterized by XRD, $\mathrm{N}_{2}$ adsorption at $-196{ }^{\circ} \mathrm{C}, \mathrm{EDX}$, TG-DTG, $\mathrm{NH}_{3}-$ $\mathrm{TPD}, \mathrm{CO}_{2}$-TPD and $\mathrm{H}_{2}$-TPR techniques.

The catalytic tests were carried out in a fixed bed quartz tube down-flow reactor at atmospheric pressure. A $\mathrm{CH}_{4}$-air mixture $(1 / 99 \mathrm{v} / \mathrm{v})$ was passed with a GHSV of $20000 \mathrm{~h}^{-1}$ through the catalyst bed $\left(1 \mathrm{~cm}^{3}\right)$ at reaction temperatures increasing from 350 to $700{ }^{\circ} \mathrm{C}$ at a rate of $1{ }^{\circ} \mathrm{C} \mathrm{min}{ }^{-1}$. The reaction products were analyzed by gas chromatography, complete selectivity to $\mathrm{CO}_{2}$ being always observed. The carbon balance was satisfactory in all runs within $\pm 2 \%$. 


\section{Results and conclusions}

$\mathrm{CuAlO}$ and $\mathrm{CuMgO}$ catalysts consist of poorly crystallized $\gamma$-alumina and well crystallized periclase $(\mathrm{MgO})$ phases, respectively. Both $\mathrm{CuMgAl}(3) \mathrm{O}$ and $\mathrm{CuMgAl}(5) \mathrm{O}$ samples contain the $\mathrm{Mg}$-Al mixed oxide phase with the periclase-like structure, while $\mathrm{CuMgAl}(1) \mathrm{O}$ presents both $\gamma$-alumina and periclase-like phases. Notably, neither $\mathrm{CuO}$ nor copper aluminate phases were detected in the calcined catalysts, suggesting a good dispersion of $\mathrm{CuO}$. A regular decrease of the surface area as well as an evolution of the acid-base equilibrium toward higher basicity was observed as the Mg content of the support increases. All the catalysts present different $\mathrm{CuO}$ species reduced below $400{ }^{\circ} \mathrm{C}$. $\mathrm{CuMgAl}(3) \mathrm{O}$ mixed oxide derived from a pure LDH precursor shows a significant amount of copper reduced in the temperature range $400-900{ }^{\circ} \mathrm{C}$, belonging to poorly reducible spinel-like phases.

The catalytic activity followed the order: $\mathrm{CuMgAl}(1) \mathrm{O} \geq \mathrm{CuAlO}>\mathrm{CuMgAl}(3) \mathrm{O}>$ $\mathrm{CuMgAl}(5) \mathrm{O}>\mathrm{CuMgO}$. The specific activity was correlated to the $\mathrm{H}_{2}$ consumption in the temperature range $100-400{ }^{\circ} \mathrm{C}$ in the TPR experiments (Figure 1), suggesting that the most reducible $\mathrm{CuO}$ species were likely involved in the methane combustion. Notably, all the catalysts display good stabilities during the methane combustion process (Figure 2). The highest activity was observed for $\mathrm{CuMgAl}(1) \mathrm{O}$ which is a mixture of $\gamma$-alumina and periclase phases containing both well distributed and aggregated $\mathrm{CuO}$ particles. It also contains high amounts of strong acid sites and basic sites of both medium and high strength.

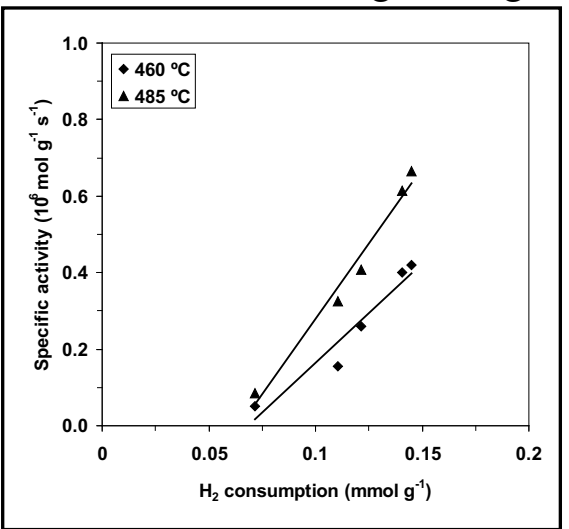

Figure 1. Specific activities vs. $\mathrm{H}_{2}$ consumption below $400{ }^{\circ} \mathrm{C}$ in the TPR experiments.

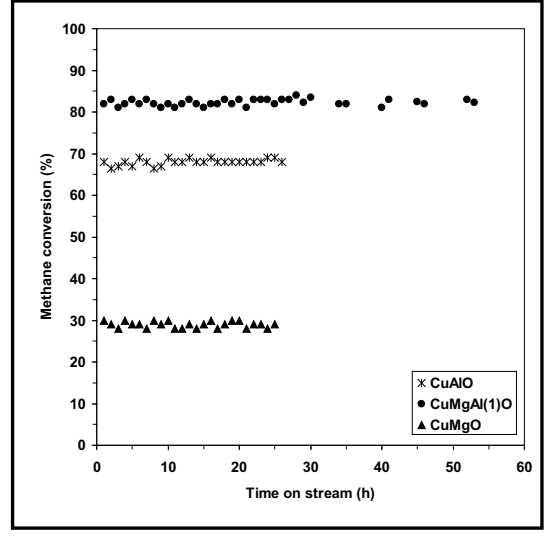

Figure 2. Effect of time on stream on the catalytic activity of the catalysts.

In conclusion, the nature of the support, which controls the surface area and the acidbase properties, allows adjusting the nature and the distribution of the $\mathrm{Cu}$-containing species and hence the catalytic activities in methane combustion.

\section{References}

Chen, J, Arandiyan, H, Gao, X \& Li, J 2015, 'Recent Advances in Catalysts for Methane Combustion', Catalysis Surveys from Asia, vol. 19, no. 3, pp. 140-171.

Li, WB, Wang JX \& Gong H 2009, 'Catalytic combustion of VOCs on non-noble metal catalysts', Catalysis Today, vol.148, no. 1-2, pp. 81-87. 